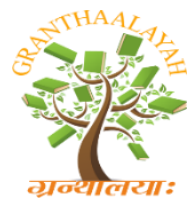

\author{
INTERNATIONAL JOURNAL OF RE
GRANTHAALAYAH \\ A knowledge Repository
}

Science

\title{
MEASUREMENT OF NORMAL SIZE OF PROSTATIC GLAND IN NORMAL SUDANESE MEN MARCH- OCTOBER 2019
}

\author{
Nagla Hussien Mohamed Khalid ${ }^{1}$, Maha Esmeal Ahmed Esmeal ${ }^{2}$ \\ ${ }^{1} \mathrm{Ph}$. D, Assistant Professor, Najran University- Kingdom of Saudi Arabia, College of Applied \\ Medical Sciences, Faculty of Radiological Sciences Department, Saudi Arabia \\ ${ }^{2} \mathrm{Ph}$. D, Associate Professor, National University- Sudan, Radiography and Medical Imaging \\ Sciences, Radiological Sciences College, Sudan
}

\begin{abstract}
Background: The prostate may become larger and begin to cause problems as male ages. Ultrasound is a commonly used imaging modality for the assessment of the prostate.

Objective: The aim of this study was to identify the normal measurements (volume and diameters) of the prostate gland in Khartoum state Sudan in normal Sudanese.

Method: This descriptive study of the study was done in Sudan teaching hospital, from March to October 2019. 60 patients were randomly selected, their age ranged from 20 to 60 years; patients with symptoms related to prostate pathologies were excluded. Transabdominal ultrasound scanning by 3.5 MHz probes was performed. And the Maximum length, width, and depth of the prostate diameters were obtained as well as the prostate volumes.

Results: The results of the study revealed that the prostate length, width and thickness Diameters mean values were $(4.88) \mathrm{cm},(3.37) \mathrm{cm}$, and $(4.55) \mathrm{cm}$ respectively, the Mean prostate volume obtained from the above parameters was $18.65 \mathrm{ml}$. The study also showed that there was an increase in the prostate volume in relation to an increase in the patient's age and weight. Transabdominal ultrasound is a respectful approach and should be used confident pathologies among Sudanese and for normal measurements.
\end{abstract}

Keywords: Prostate Gland; Ultrasound; Diameters; Prostate Volume.

Cite This Article: Nagla Hussien Mohamed Khalid, and Maha Esmeal Ahmed Esmeal. (2020). "MEASUREMENT OF NORMAL SIZE OF PROSTATIC GLAND IN NORMAL SUDANESE MEN MARCH- OCTOBER 2019." International Journal of Research - Granthaalayah, 8(2), 163-167. https://doi.org/10.29121/granthaalayah.v8.i2.2020.201.

\section{Introduction}

The human prostate, situated at the midpoint of the male pelvic floor, is much like the junction for the male genitourinary system as it can affect both fertility and urinary function. Definitely, the prostate holds significant health associations for a host of benign and malignant conditions. (1) The parenchyma has 30-50 small tubule-alveolar glands, which have 15-30 excretory ducts open 
indirectly in prostatic urethra these ducts organized as flow mucosal small open direct in urethra, submucosal, middle. Outer external glands form the main duct secret most of the prostatic secretion which is milky alkaline fluid to neutralize vaginal acidity rich in proteolytic enzymes and acid phosphate enzymes. (2) Structure of the prostate pronounced traditionally as having five lobes anterior, posterior, and median and two lateral lobes. But more helpfully the gland is described as its internal architecture as having three glandular zones (peripheral, central and transition)with the non-glandular isthmus anteriorly (3) The standard size of the gland differs according to so many recourses: while it's $20 \mathrm{gm}$ in young, more than $40 \mathrm{gm}$ is Benign prostatic hypertrophy (4), or the mean weightis11gm ranging from (7-16) gm it's in some books up to 25 gm. (5)

Among the various imaging modalities used to determine prostatic volume and weight, ultrasound is the cheapest, more readily available, does not require elaborate patient preparation, offers fast examination time and free of ionizing radiation (6). Ultrasound examination of the prostate to determine its volume may be performed transabdominally, transrectally, transurethral or transperineally $(7,8)$. Endorectal (transrectal) ultrasonography has become the dominant imaging modality for the evaluation of the prostate. It visualizes the zonal anatomy and volume better than an abdominal or transperineally ultrasound scan as well as imaged fully the normal or minimally enlarged gland (8). The advantages of transabdominal ultrasound are the procedure can be performed quickly, bed-side, not radiated and non-invasive (9) A knowledge of the normal prostate gland volume and an understanding of the prostate growth rate and how it changes with age is very important to the urinary tract symptoms and benign prostatic hypertrophy in men (10). The prostate should be imaged in its entirety in at least two orthogonal planes, sagittal and axial or longitudinal and coronal, from the apex to the base of the gland. An estimated volume is determined from measurements in three orthogonal planes. (11) The volume of the prostate may be correlated with the PSA level. Alternatively, the prostate volume can be calculated using prostate planimetry, which allows greater accuracy by accommodating individual variations in prostate shape. (12)

This study was conducted to evaluate the normal prostatic gland measurement in normal Sudanese Men.

\section{Materials and Method}

A descriptive prospective study was carried out in order to state the normal measurements of the prostate gland in Khartoum state hospital- Sudan. The population of this was an adult Sudanese patient who referred for abdominal US scans in these hospitals, who are not suffering from any symptoms related to prostate diseases. The sample size of this study will consist of 60 cases, and they will be randomly selected during the duration of the study (march-to October 2019) were included. Patients who are not Sudanese are excluded, patients who find to have prostatic disease symptoms or who are known cases or detected to have prostatic pathology during US scan and patients refused to be candidate of study will be all excluded from this study.

\section{Equipment}

Ultrasound machines, personal computer measurement equipment for heights, and weights of the patient's. 


\subsection{Methods}

\section{Scanning Technique}

Ultrasound examination was used Trans Abdominal probe with 3.5 to $5 \mathrm{MHz}$ through the following steps The patient needs optimal bladder filling if not, more than40 Ounces should be taken by the patient and note that over distended bladder can push. The pelvic organs out of view, so we may need to request the patient to void partially (6) Different sectional images (longitudinal and transverse) were obtained and measurements taken in these planes.

\section{Data Collection Method}

The data collected by using special data collection sheet, These data were collected in the following ways: The personal data consists of variables: patient's index, age, height and weight, The sonographic finding data include variables which are: Age and hight and weigh of the sample also the height, width, depth, volume of the prostate gland.

\section{Data Analysis}

The data will be analyzed by using Statistical Packaged for Social Studies (S P S S version 23).

\section{Ethical Approval}

No patient identification was published and also data was kept in a personal computer with a personal password.

\section{Result}

Table 1: Frequency distribution of age $(n=60)$

\begin{tabular}{|l|l|l|}
\hline Age-Years & Frequency & Percentage \\
\hline $20-30$ & 28 & 46 \\
\hline $31-40$ & 18 & 30 \\
\hline $41-50$ & 5 & 8.33 \\
\hline $51-60$ & 9 & 15 \\
\hline Total & 60 & 100 \\
\hline
\end{tabular}

Table 2: Frequency distribution of marital status $(n=60)$

\begin{tabular}{|l|l|l|}
\hline Status & Percent & Percent \\
\hline Married & 37 & 61.66 \\
\hline Single & 23 & 38.33 \\
\hline Total & 60 & 100 \\
\hline
\end{tabular}

Table 3: Minimum, maximum, mean \pm Std. Deviation for age, weight, height, BMI and prostate measurements.

\begin{tabular}{|l|l|l|l|l|l|}
\hline Variables & $\mathbf{N}$ & Minimum & Maximum & Mean & Std Deviation \\
\hline Age & 60 & 20 & 60 & 40 & 11.10 \\
\hline Height & 59 & 154 & 197 & 175.5 & 10.33 \\
\hline Weight & 59 & 52 & 98 & 75 & 12.40 \\
\hline BMI & 59 & 14.9 & 33.2 & 23.90 & 8.30 \\
\hline
\end{tabular}




\begin{tabular}{|l|l|l|l|l|l|}
\hline length & 60 & 2.46 & 4.84 & 4.88 & .5760 \\
\hline Width & 60 & 2.25 & 4.5 & 3.37 & .5335 \\
\hline Thickness & 60 & 2.3 & 4.5 & 4.55 & .448 \\
\hline Volume & 60 & 8.3 & 29 & 18.65 & 6.431 \\
\hline
\end{tabular}

\section{Discussion}

The aim of this study was to measure of the normal prostate gland (volume, and dimensions) in Sudanese people using trans-abdominal ultrasound and to state these measurements in relation to their individual characteristics. So about 60 patients were selected randomly, who have no complaints related to prostate pathology. The results confirmed that there is a positive linear relationship between the age of Patients and their prostate volumes (Table 3), so that' when patient's age Increases the prostate volume also increases, table (table 3). This positive Relationship is expected because aging is a risk for prostate enlargement $\mathrm{BPH}$, and this result agrees with previous studies. $(13,14,15)$ Also, another positive linear relationship between the prostate volume and patient's Weight Table (3), so that an increase in body weight there should be an increase in prostate volume, table(3). This positive relationship is also Expected because an increase in patient weight increases fats concentration in the Body, which was the main source of steroid hormones that influence the growth of the prostate gland. Also, this result agrees with previous studies. The results of the study revealed that the prostate length, width, and thickness of Diameters mean values were $(4.88) \mathrm{cm},(3.37) \mathrm{cm}$, and $(4.55) \mathrm{cm}$ respectively, the Mean prostate volume obtained from the above parameters was $18.65 \mathrm{ml}$. The study also showed that there was an increase in the prostate volume in relation to increase in the patient's age and weight. $(13,14,15)$

\section{Conclusion}

The study concluded and revealed that the prostate length, width and thickness Diameters mean values were $(4.88) \mathrm{cm},(3.37) \mathrm{cm}$, and $(4.55) \mathrm{cm}$ respectively, the Mean prostate volume obtained from the above parameters was $18.65 \mathrm{ml}$. The study also showed that there was an increase in the prostate volume in relation to the increase in the patient's age and weight. Trans-abdominal ultrasound is a respectful approach and should be used confidently in the measurement and evaluation of the prostate gland size pathologies among Sudanese

\section{References}

[1] Christopher R. Porter Erika M. Wolff Editors: rostate Ultrasound Current Practice and Future Directions: Springer Science Business Media New York 2015: DOI 10.1007/978-1-4939-1948-2 page 3

[2] SNELL, R.S.1995.Clinical anatomy for medical students, Little, Brown Medical Division.

[3] RYAN,S.,MCNICHOLAS,M.\&EUSTACE,S.J.2011.AnatomyforDiagnosticImagingE-Book, Elsevier Health Sciences

[4] RUMACK,C.M.,WILSON,S.R.,CHARBONEAU,J.W.\&LEVINE,D.2011.Diagnosticultrasound, Elsevier/Mosby.

[5] BUTLER, P., MITCHELL, A. W. \& ELLIS, H. 1999. Applied radiological anatomy, Cambridge University Press.

[6] Hricak H, Jeffrey RE. Evaluation of prostate size; a comparison of ultrasound and magnetic resonance imaging. Urol. Radiol. 1987; 9: 1 - 5. 
[7] Miller SS, Garvey WHH, Chrisie AD. The evaluation of prostate size by ultrasound scanning: a preliminary report. Brit. J. Urol. 1973; 45: 187 - 189.

[8] Styles RA, Neal DE, Powel PH. Reproducibility of measurement of Comparison of transrectal and transabdominal methods. Eur. Urol. 1988; 14: 26 6- 269.

[9] Walz J, Graefen M, Chun FK, et al., High incidence of prostate cancer detected by saturation biopsy after previous negative biopsy series, Eur Urol. 2006, 498-505.

[10] Adrianne MW, Inpakal S, Landis PK, Moser C, Christens- Barry W, Carter HB, Metter EJ, Partin AW. Prostatic growth rate determined from MRI data: Age-related longitudinal changes. J. Andrology. 1999; 20: 472 - 480.

[11] Halpern EJ. Measurement of the prostate gland. In: McGahan J, Goldberg BB (eds). Atlas of Ultrasound Measurements. 2nd ed. Chicago, IL: Mosby Yearbook; 2005.

[12] McAchran SE, Dogra V, Resnick MI. Office urologic ultrasound. Urol Clin North Am 2005; 32:337-352,

[13] ABDALLAH, Y.H.Y.2015.Measurement of Normal Prostate Volume in Healthy Adult Sudanese: Using Ultrasound. Sudan University of Science and Technology.

https://www.google.com.sa/url?sa=t\&rct=j\&q=\&esrc=s\&source=web\&cd=1\&cad=rja\&uact=8\& ved=2ahUKEwjlwKqblJnnAhUHzhoKHTG2DqMQFjAAegQIARAC\&url=http\%3A\%2F\%2Fre pository.sustech.edu\%2Fbitstream\%2Fhandle $\% 2$ F123456789\%2F22285\%2FMeasurement $\% 252$ 0of\%2520Prostate\%2520...\%2520.pdf\%3Fsequence\%3D1\%26isAllowed\%3Dy\&usg=AOvVaw 1MXvvg2IlKnG_fVI-t1589

[14] Edmund K. Brakohiapa, MBChB, FWACS, Benard O. Botwe, MSc, \& Benjamin D. Sarkodie, MBChB, FWACS: Prostatic volume determination by transabdominal ultrasonography: Does accuracy vary significantly with urinary bladder volumes between 50 to $400 \mathrm{~mL}$ ?: J Med Radiat Sci xx (2019) 1-10 : doi: 10.1002/jmrs.320

[15] Tsige M1, Atnafu A. Sonographic measurement of normal prostate volume and pattern of change with age among male adult Ethiopia patients at Black Lion Specialized Hospital:2011: Oct;49(4):361-6.

*Corresponding author.

E-mail address: najlabashab @yahoo.com 